\title{
Apatite Wollastonite-Reinforced Hydroxyapatite Biocomposites
}

\author{
F. ÇALIŞKAN* \\ Sakarya University, Faculty of Technology, Department of Metallurgical and Materials Engineering, \\ Sakarya University, 54187, Sakarya, Turkey
}

\begin{abstract}
The paper is focused on the reinforcement of hydroxyapatite (HA) by apatite wollastonite (AW) because of its aptitude for combining biocompability with mechanical properties superior to those of the bone. HA powders were produced by thermal extraction technique involving calcination from natural source. HA-AW biocomposites containing from 0 to $20 \mathrm{wt} . \%$ of $\mathrm{AW}$ in particulate form were prepared starting with wet ball milling during $24 \mathrm{~h}$, followed by powder metallurgical processes using HA powders calcined at $800^{\circ} \mathrm{C}$, followed by compaction by cold pressing and by cold isostatical pressing at $250 \mathrm{MPa}$ and subsequent sintering at $1100-1300^{\circ} \mathrm{C}$. The phases and compositions in the resulting products were identified by XRD and XRF. Reinforcement particle distribution were investigated on polished surfaces of the sintered samples by SEM analysis and by optical microscopy. Mechanical properties of the sintered samples was evaluated via Micro Vickers hardness testing.
\end{abstract}

DOI: 10.12693/APhysPolA.129.665

PACS/topics: 81.05.- $-\mathrm{t}$

\section{Introduction}

Daily losses of tissues or parts of human bodies as a result of injuries or diseases, deteriorates quality of life for many people at a significant socioeconomic cost in an aging population [1-2]. Calcium phosphate ceramics and bioactive glasses, which can bond to bone and enhance bone tissue formation, have been discovered more than 30 years ago as bone substitutes [3]. The most widely used forms of calcium phosphate ceramics are tricalcium phosphate (TCP) and hydroxyapatite (HA) [45]. HA has a similar structure to the apatite phase of bone and has been shown to be osteoconductive and to enhance the growth of bone cells [6-7]. The HA is less expensive than most of the inorganic fillers used today, and it is an attractive material for bone and tooth implants [8-10]. Several attempts have been made to combine the advantageous properties of HA with hard reinforcement. Glass ceramics (GC), which is non-toxic, have no inflammatory and pyrogenetic responses, has a strong potential for application as a reinforcement material in HA matrix [11-12]. GC exhibits better mechanical properties than HA [13]. The candidate glass for incorporation into HA should be phosphate-based glass closely similar to the composition of HA [14]. Our aim was to manufacture a $\mathrm{HA} / \mathrm{AW}_{\mathrm{P}}$ composite with both optimum density and mechanical properties for use as an implant. For this purpose, hydroxyapatite-apatite wollastonite bioceramic composites were prepared with AW additions in the range from $0 \mathrm{wt} . \%$ to $20 \mathrm{wt} . \%$.

\section{Materials and methods}

The present study was carried out in three steps, extraction and production of HA powder, fabrication

\footnotetext{
*e-mail: fcaliskan@sakarya.edu.tr
}

of composite, and their characterisation, respectively. HA powder was manufactured from bovine bone by thermal extraction method being fairly inexpensive technique. The method includes three steps; crushing to small pieces, boiling up at $100^{\circ} \mathrm{C}$ for $3 \mathrm{~h}$, burning out organic materials. Afterwards, the precursor was heat treated in ashing chamber furnace (PLF 130/9 model). AW powder was produced in Gizem Frit A.Ş. Both HA and AW powders were grinded by planetary milling and were sieved through a $30 \mu \mathrm{m}$ screen. The powders were wet mixed by ball milling for $24 \mathrm{~h}$. Following the mixing, rotary evaporator was used to homogeneously remove alcohol from the slurry at $90^{\circ} \mathrm{C}$ for $1 \mathrm{~h}$. The powder was pressed into a steel die $(\varnothing 12 \mathrm{~mm})$ under $50 \mathrm{MPa}$ and was cold isostatically pressed under $250 \mathrm{MPa}$. Particle size distribution (PSD) analyses of the used powders were performed on the Microtrack S3500. X-ray fluorescence spectrometer (S8 TIGER) and XRD (Rigaku Dimaks 2200) were used to reveal the chemical composition. The final densities of the sintered samples were measured using the Archimedes principle in distilled water. Scanning electron microscopy (SEM) (TESCAN VEGA3 SB) was performed to examine densification and particle distribution.

\section{Results and discussion}

\subsection{XRD and XRF analyses of the powder}

The XRD pattern of the produced HA powder in Fig. 1 shows that all peaks belong to $\mathrm{HA}$ phase $\left[\mathrm{Ca}_{10}\left(\mathrm{PO}_{4}\right)_{6}(\mathrm{OH})_{2}\right.$, ICDD: 01-074-0565] and are the characteristic peaks of HA. Consequently, the resulting product is a mono-phase HA ceramics. Results of XRF analysis from Table I show that the synthetic $\mathrm{HA}$ as control sample includes mainly $\mathrm{CaO}$ and $\mathrm{P}_{2} \mathrm{O}_{5}$, and $\mathrm{Na}_{2} \mathrm{O}, \mathrm{MgO}, \mathrm{K}_{2} \mathrm{O}$ impurities. This is because synthetic HA was synthesized via only reaction of calciumphosphate, therefore it could not involve any other component. The produced HA powder contains mainly $\mathrm{CaO}$ 
and $\mathrm{P}_{2} \mathrm{O}_{5}$, and $\mathrm{Na}_{2} \mathrm{O}, \mathrm{MgO}, \mathrm{K}_{2} \mathrm{O}, \mathrm{SiO}_{2}, \mathrm{ZnO}$, etc. as impurities. This difference arises from the differences in the raw materials and in the production methods. However, the main components and their amounts in both powders are very close each other. The composition of original bone mineral is much more complex and includes additional ions such as silicon, carbonate and zinc [15]. That is to say, the produced HA was much more similar to the original bone composition.

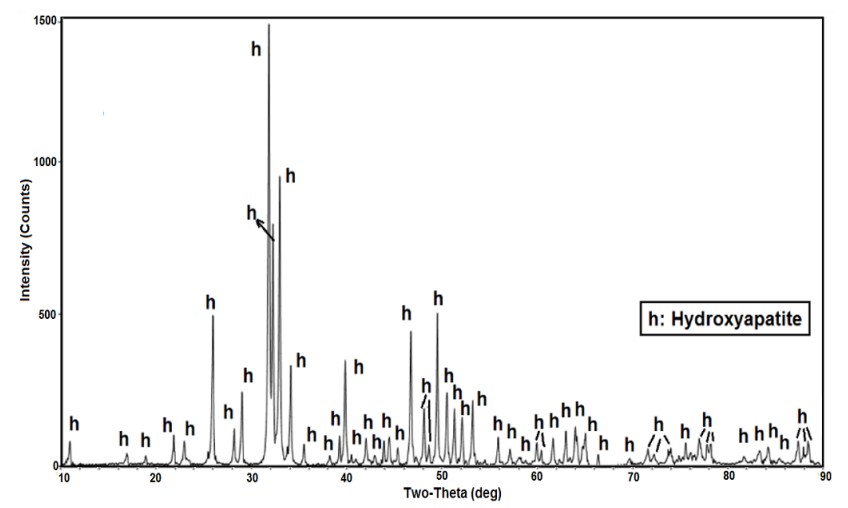

Fig. 1. The XRD pattern of the produced HA powder.

TABLE I

XRF results for both the synthetic HA and the produced HA powders.

\begin{tabular}{c|c|c}
\hline [wt.\%] & produced HA & synthetic HA \\
\hline $\mathrm{CaO}$ & 59.06 & 64.68 \\
$\mathrm{P}_{2} \mathrm{O}_{5}$ & 37.26 & 34.77 \\
$\mathrm{Na}_{2} \mathrm{O}$ & 1.72 & 0.475 \\
$\mathrm{MgO}$ & 1.67 & 0.064 \\
$\mathrm{~K}_{2} \mathrm{O}$ & 0.0611 & 0.0148 \\
$\mathrm{SiO}_{2}$ & 0.058 & - \\
$\mathrm{SrO}$ & 0.0558 & - \\
$\mathrm{SO}_{3}$ & 0.053 & - \\
$\mathrm{ZrO}_{2}$ & 0.013 & - \\
$\mathrm{ZnO}$ & 0.004 & -
\end{tabular}

TABLE II

$\mathrm{XRF}$ results for both the produced AW and the reference AW powders.

\begin{tabular}{c|c|c}
\hline \hline [wt.\%] & produced AW & reference AW \\
\hline $\mathrm{CaO}$ & 48.440 & 48.868 \\
$\mathrm{SiO}_{2}$ & 33.447 & 33.769 \\
$\mathrm{P}_{2} \mathrm{O}_{5}$ & 13.679 & 13.478 \\
$\mathrm{Al}_{2} \mathrm{O}_{3}$ & 2.008 & 1.862 \\
$\mathrm{MgO}$ & 1.934 & 1.936 \\
$\mathrm{Na}_{2} \mathrm{O}$ & 0.103 & 0.008 \\
$\mathrm{Fe}_{2} \mathrm{O}_{3}$ & 0.051 & 0.064 \\
$\mathrm{TiO}_{2}$ & 0.061 & 0.007 \\
$\mathrm{~K}_{2} \mathrm{O}$ & 0.152 & - \\
$\mathrm{ZrO}_{2}$ & 0.054 & -
\end{tabular}

$\mathrm{XRF}$ results for both the produced AW and the reference sample are given in Table II. As can easily be seen in Table II, $\mathrm{CaO}, \mathrm{P}_{2} \mathrm{O}_{5}$ and $\mathrm{SiO}_{2}$ are the main phases in AW. The overall XRF results show very similar composition between the reference and the produced AW. These compositions are coherent with the composition invented by Kukubo et al. in 1982 [16].

\subsection{Particle size analysis}

Figure 2a shows that after the grinding process, the HA powder had bimodal particle size distribution (PSD). That is, it mainly had two accumulation modes. PSD has two peaks in the ranges of $1-2 \mu \mathrm{m}$ and $10-15 \mu \mathrm{m}$, respectively $(d(0.5)=6.872 \mu \mathrm{m})$. Specific surface area of the HA powder was $1.99 \mathrm{~m}^{2} / \mathrm{g}$. The PSD characteristics of AW powder from Fig. $2 \mathrm{~b}$ are akin to those of the HA (Fig. 2a). Accumulation points of PSD were at $0.8 \mu \mathrm{m}$ and $20 \mu \mathrm{m}$. In addition, the AW had slightly coarse size $(d(0.5)=8.902 \mu \mathrm{m})$. Specific surface area of the HA powder was $2.07 \mathrm{~m}^{2} / \mathrm{g}$. In conclusion, the obtained powders used for production of composite had a similar PSD and similar grain size ranges.
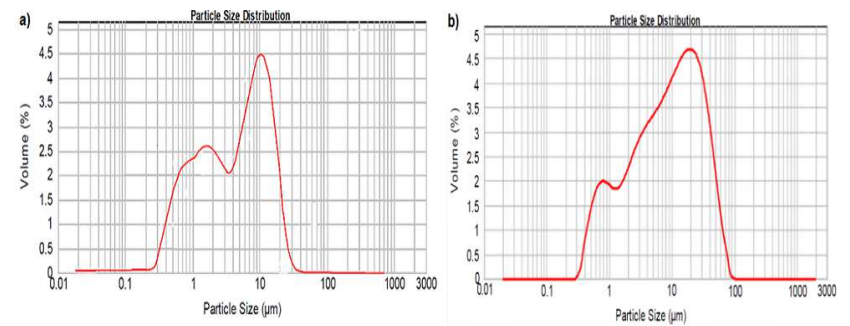

Fig. 2. (a) PSD analysis of the HA ceramic powder, (b) PSD analysis of the AW glass ceramic powder.

\subsection{Densification behaviour of the compositions}

Figure 3 shows the effect of time and temperature on densification behaviour of $\mathrm{HA}-\mathrm{AW}_{\mathrm{P}}$ compositions sintered in the range of $1100-1300^{\circ} \mathrm{C}$. A decrease in the relative density can be seen with the increasing temperature. This behaviour can be attributed to phase decomposition at elevated temperatures, because, the clear decrease in density values can be seen at $1300^{\circ} \mathrm{C}$. On the other hand, the increase of reinforcement ratio can induce some difficulties, such as pressing problems. This phenomena is due to the fact that AW ceramic particles are harder than those of the matrix.

Contact of AW particles with the matrix leaves pores which limit the possibility of reaching high density. However, previous studies show that an increase in reinforcement ratio can enhance mechanical properties of composite. Densification is the key factor in selection of optimum processing parameters. Shrinkage ratio has decreased with the increase of $\mathrm{AW}_{\mathrm{P}}$ ratio (from 0 to $15 \%$ ) for all temperatures, which results in lower densities. The highest densities were achieved for the samples sintered at $1275^{\circ} \mathrm{C}$ for $120 \min (\max .97 .37 \%$ R.D.). 


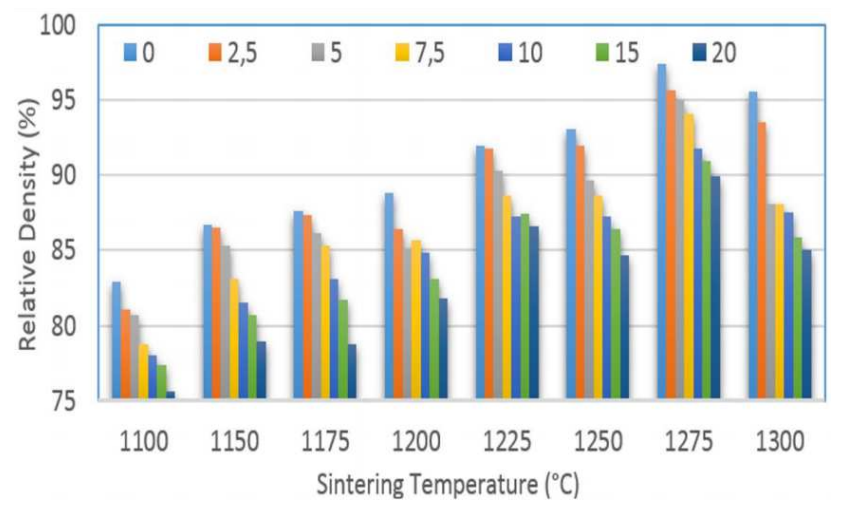

Fig. 3. Relative density of the sintered HA-AW $\mathrm{P}$ bioceramic composites (0-20 wt.\%) as a function of sintering temperature.

\subsection{Mechanical properties}

Results of microVickers hardness tests are shown in Fig. 4 for all sintering temperatures. From the obtained values it can be seen that an increase in microhardness was observed at elevated sintering temperatures, as might be expected since density is also increasing with the sintering temperature. This clear increase is due to the possibility of diffusion at higher temperatures. It is hard to transport materials to pores between close particulates. While higher values of microhardness are observed in samples with 10 wt.\% of AW at lower sintering temperatures, higher values of microhardness are observed in samples with 15 wt.\% of AW at higher sintering temperatures. While the highest hardness value $\left(476 \mathrm{kgf} / \mathrm{mm}^{2}, \mathrm{Hv} 1\right)$ was achieved with HA$\mathrm{AW}_{\mathrm{P}}(15 \mathrm{wt} . \%)$ sintered at $1250^{\circ} \mathrm{C}$ for $2 \mathrm{~h}$, the sintered $\mathrm{HA}$ with 0 wt. $\% \mathrm{AW}_{P}$ gave $348 \mathrm{kgf} / \mathrm{mm}^{2}(\mathrm{Hv} 1)$ at the same conditions.

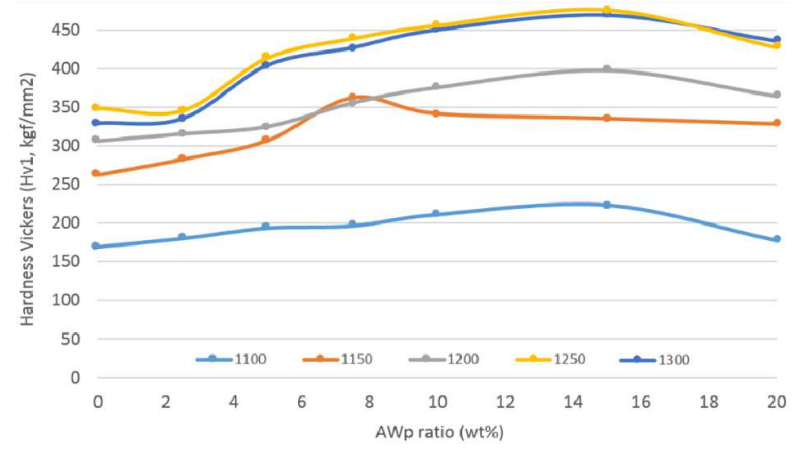

Fig. 4. Micro Vickers hardness values $\left(\mathrm{kgf} / \mathrm{mm}^{2}\right)$ for the samples sintered at various sintering temperature for $120 \mathrm{~min}$.

\subsection{Scanning electron microscopy and optical microscopy of the biocomposites}

Microstructure of biocomposites is shown in Fig. 5 and Fig. 6. As can be seen, the samples have reached high densification levels. Addition of AW to the matrix has caused initiation of pore forming in Fig. 5b. Contrary to Fig. 5a, Fig. 6a-c show uniformly distribution of AW in the matrix. Even when the reinforcement ratio was increased, homogeneous distribution still could be achieved. This reinforcement uniformity helped to improve hardness of the biocomposite in the study.
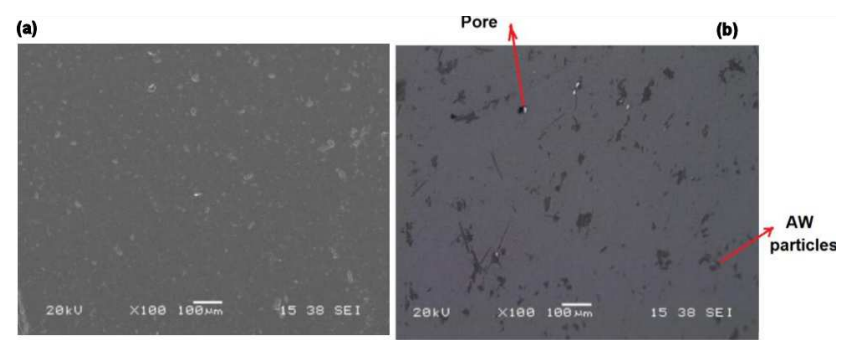

Fig. 5. SEM micrograph of the sintered HA sample with 0 wt.\% of AW (a), 2.5 wt.\% of AW (b) sintered at $1275^{\circ} \mathrm{C}$ for $2 \mathrm{~h}$.

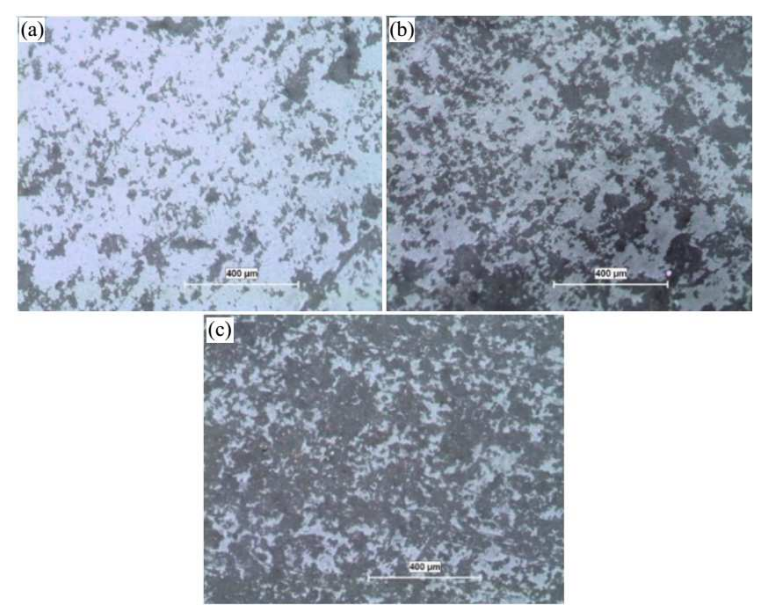

Fig. 6. Optical micrographs of the sintered sample with 7.5 wt.\% of AW (a), 15 wt.\% of AW (b) and 20 wt. $\%$ of AW (c).

\section{Conclusions}

A major achievement in this study is the production of calcium phosphate composites with high density and having a higher hardness than the monolithic HA. AW was selected for having both biocompability and higher hardness than HA. Density results have shown that fabrication of biocomposite having both $97 \%$ density and $476 \mathrm{kgf} / \mathrm{mm}^{2}$ hardness was achieved using sintering at $1250{ }^{\circ} \mathrm{C}$ for $2 \mathrm{~h}$ with $\mathrm{AW}$ content of $15 \mathrm{wt} . \%$. Hardness of monolithic HA was substantially improved with $\mathrm{AW}_{\mathrm{P}}$ reinforcement up to $36 \%$. SEM investigations have revealed uniform AW distribution and nearly dense microstructures. In conclusion, the processing conditions of the HA-AW $\mathrm{P}_{\mathrm{P}}$ biocomposites and their properties were considerably enhanced via pressureless sintering methods. This experiment has proved that the mechanical properties of the composite can be satisfactory for use in implants. In particular, the 15 wt.\% HA composite can be used as a substitute in dental implants. 


\section{References}

[1] M.S. Chapekar, J. Biomed. Mater. Res. 53, 617 (2000).

[2] R. Ahmed El-Ghannam, J. Biomed. Mater. Res. 69A, 490 (2004).

[3] K. Deepak, B.T. Pattanayak, B.T. Rao, T.R. Rama Mohan, J. Sol-Gel Sci. Technol. 59, 432 (2010).

[4] R.O. Oreffo, J.T. Triffitt, Bone 25, 5S (1999).

[5] Y. Horisaka, Y. Okamoto, N. Matsumoto, Y. Yoshimura, J. Kawada, K. Yamashita, T. Takagi, Clin. Orthop. 268, 303 (1991).

[6] B.A. Doll, H.J. Towle, J.O. Hollinger, A.H. Reddi, J.T. Mellonig, J. Periodontol. 61, 745 (1990).

[7] P.S. Eggli, W. Muller, R.K. Schenk, Clin. Orthop. 232, 127 (1988).

[8] C. Domingo, R.W. Arcís, A. López-Macipe, R. Osorio, R. Rodríguez-Clemente, J. Murtra, M.A. Fanovich, M. Toledano, J. Biomed. Mater. Res. 56, 297 (2001).
[9] A.R. Ibrahim, Y.T. Zhou, X. Li, L. Chen, Y. Hong, Y. Su, H. Wang, J. Li, Mater. Res. Bull. 62, 132 (2015).

[10] P. Hui, S.L. Meena, G. Singh, R.D. Agarawal, S. Prakash, J. Miner. Mater. Character Eng. 9, 683 (2010).

[11] T. Kokubo, S. Ito, M. Shigematsu, S. Sanka, T. Yamamuro, J. Mater. Sci. 22, 4067 (1987).

[12] T. Kitsugi, T. Yamamuro, T. Kokubo, M. Ono, J. Biomed. Mater. Res. 21, 1109 (1987).

[13] R.D. Rawlings, P.S. Rogers, P.M. Stokes, High Tech Ceramics, Elsevier, Amsterdam 1987, p. 73.

[14] J.D. Santos, J.C. Knowles, R.L. Reis, F.J. Monteriro, G.W. Hastings, Biomaterials 15, 5 (1994).

[15] J.E. Davies, Bone Engineering, Em Squared, 2000.

[16] T. Kokubo, M. Shigematsu, Y. Nagashima, M. Tashiro, T. Nakamura, T. Yamamuro, S. Higashi, Bull. Inst. Chem. Res. 60, 260 (1982). 